مقاله بزوهشى

مجله دانشَاه علوم يزشكى رفسنجان

دوره +r، شهريور ••ll

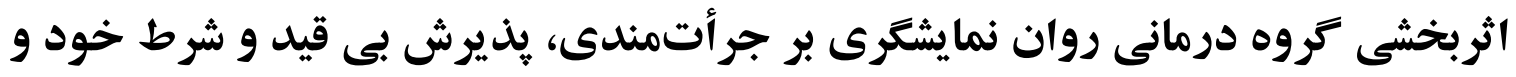

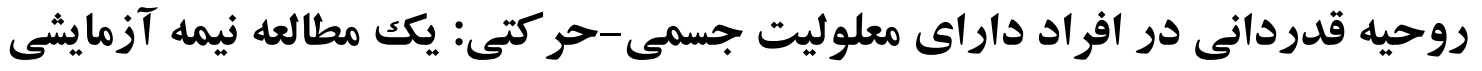

محمدعلى مكارم'، زهر ا يوسفى

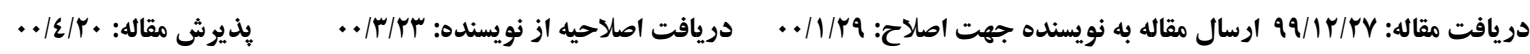
جكيده زمينه و هدف: بهبود حالات روانشناختى معلولين جسمى-حركتى مىتواند به آسانتر شدن زندكى آنان كمك نمايد. اين يروهش با هدف تعيين اثربخشى گروه درمانى روان نمايشگرى بر جرأتمندى، يذيرش خود و روحيه قدردانى در افراد داراى معلوليت جسمى -حركتى شهر اصفهان انجام شده است.

مواد و روشها: روش يزوهش حاضر نيمه آزمايشى با طرح كروه آزمايش و كنترل با ريشآزمون و رِآزمون بود. جامعه

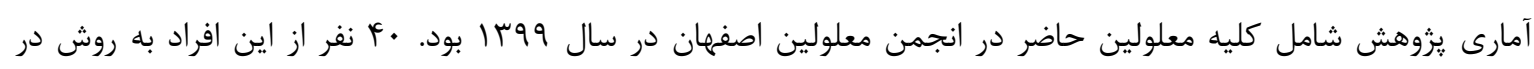

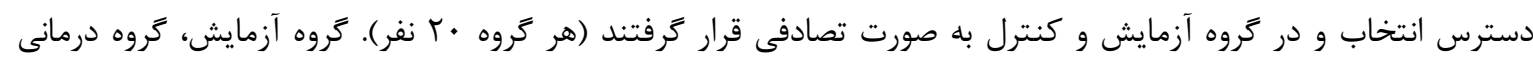
روان نمايشگرى را طى هشت جلسه نود دقيقهاى دريافت كردند، در حالى كه بر روى كروه كنترل مداخلهاى انجام نشد. براى

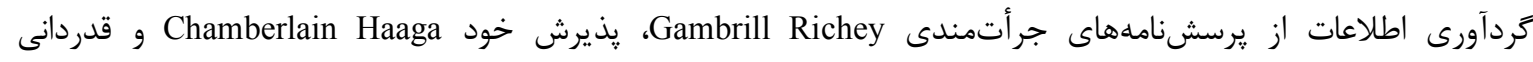
استفاده شد. دادهها توسط آمار توصيفى (ميانگين و انحراف استاندارد) و آمار استنباطى (تحليل كواريانس جند رئد متغيره) تجزيه و تحليل شدند.

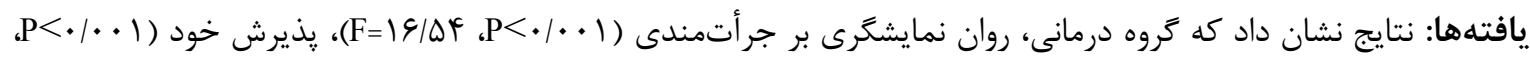

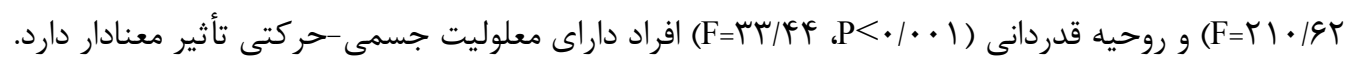
نتيجهَيرى: روش روان نمايشگرى بر بهبود جرأتمندى، پذيرش بى قيد و شرط خود و روحيه قدردانى در افراد داراى معلوليت جسمى -حر كتى شهر اصفهان مؤثر بود. بنابراين مىتوان اين روش را براى بهبود متغيرهاى مذكور در بين معلولين جسمى -حركتى مد نظر قرار داد. وازههاى كليدى: گروه درمانى روان نمايشگرى، جرأتمندى، پذيرش بى قيد و شرط خود، قدردانى، افراد داراى معلوليت جسمى -حر كتى

1- دانشجوى كارشناسى ارشد روانشناسى بالينى، دانشكده روانشناسى و علوم تربيتى، دانشگاه آزاد اسلامى واحد اصفهان (خوراسگان)، اصفهان، ايران

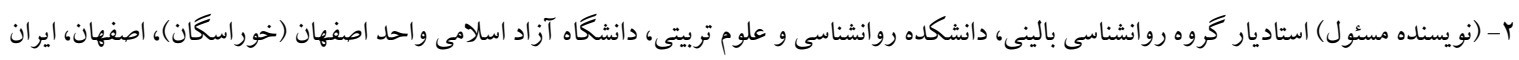

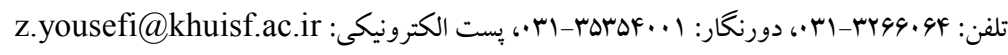


r Y أربخشى گروه درمانى روان نمايشخرى بر جرأتمندى، يذيرش بى قيد و شرط خود و روحيه قدردانى در افراد ...

با اين ادراى همراه است كه فرد منفعتى دريافت كرده كه

مقدمه

سزاوار آن نبوده بلكه اين منفعت به دليل نيات خوب فرد ديخرى به او رسيده است [ه]. در تبيين شناختى قدردانى، افراد تلاشهايى را كه ديخران به دليل رفاه و بهزيستى آنان انجام مىدهند، به ياد مى آورند. به عبارت ديخر، تصديق مى كنند كه فرد خير آن نيكى را از روى قصد و به صورت دلخواه انجام داده است در اينجا جزء شناختى قدردانى مشخص مىشود كه عبارت است از ادراك ما از عمل فرد كمك كننده (خير)، اخر افراد قصد فرد كمك كننده را انسانى و نوع دوستانه ارزشيابى كنند و كمكى را كه به آنان شده است را ارزشمند بدانند، در اين صورت احساس مىكنندكه بايد قدردان وى باشند [ع]. به هرحال تاكنون در خصوص افراد داراى معلوليت جسمى-حركتى روشهايى براى بهبود متغيرهاى روانشناختى آنان انجام شده است از جمله تأثير مشاوره گروهى به روش تحليل رفتار متقابل بر كاهش افسردگى معلولان جسمى -حركتى [V]، اثربخشى معنادرمانى بر بهبود عزت نفس [^] و اثربخشى آموزشهاى مهارتهاى اجتماعى بر هوش هيجانى [9]. يكى ديخر از روشهايى كه تا به حال كمتر در جامعه معلولان خصوصاً افراد داراى معلوليت جسمى-حركتى مورد توجه قرار گرفته است گروه درمانى با رويكرد روان نمايشگرى (Psychodrama) مىباشد. روان نمايشگرى رويكردى ويزه براى تسهيل آزادسازى هيجانات دربند به منظور سازگًاى و ايجاد رفتارهاى جديد و همجنين شناخت خود مىباشد [ [.]]. اين روش بر خودجوشى،

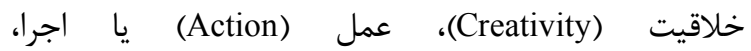
خودآشكارسازى (Self-disclosure)، قبول خطر درگير شدن
يكى از نكات مهم براى كمكرسانى به معلولين جسمى حركتى (Physical-movement disabled individuals) بهبود توانمندىهاى اجتماعى آنان است تا بتوانند از پس امور روزمره زندگى خود برآيند. در اين ميان جرأمندى

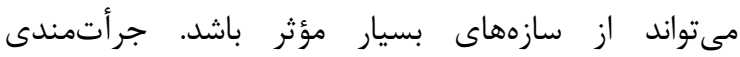
(Assertiveness)، توانايى افراد جهت برقرارى نمودن روابط بين فردى مناسب در تعاملات اجتماعى است و از طريق آن فرد افكار و احساسات خود را به طور مثبت و با رعايت حقوق ديگران بيان مىكند. بدين ترتيب فرد حقوق خود را در روابط بين فردى با در نظر گرفتن حقوق ديگران به دست مى آورد. از طرفى ديخر هنگامى كه معلول، معلوليت خويش را نيذيرد، نمىتوان انتظار داشت كه در بعد جسمانى و كنار آمدن با مشكل جسمانى خود موفق شود [1]. افراد معلول جسمى-حركتى در زمينههاى شناخى و عelf- عاطفى مربوط به عزت نفس و يذيرش خود acceptance) شواهد نشان مىدهد كه عزت نفس و رِيرش خود يايين است [r]. يذيرش خود رضايت شخص از خودش است. اين رضايت شامل درك خود و آكاهى واقعى از نقاط قوت و ضعف خود است. افراد هر خه بيشتر خود را بِيذيرند احتمال بيشترى خواهد داشت كه ديخران را نيز بيذيرند [ب] و باعث مى گردد تا روحيه قدردانى (Gratitude spirit) در آنان يرورش يابد. Renshaw قدردانى را يك متغير منحصر به فرد مى داند كه تأثير بر رفاه و سلامت روان دارد [F]. قدردانى در روانشناسى حالتى شناختى و عاطفى است. اين حالت اغلب 
كروه كنترل و آزمايش) هـ/ ه و توان آمارى •^ درصد در نظر ترفته شد كه حجم نمونه M نفر به دست آمد. اما به علت نياز روش سايكودرام به نمايش روايت زندگى هر يك از اعضاء و لزوم بازخورد اعضاء كروه به ميزان زياد و همجنين نقش درمانكَر به عنوان كاركردان براى تنظيم صحنههاى زندگى و آموزشهاى مرتبط، حجم تروه بايد به گَونهاى باشد كه اين فرصت براى همه اعضاء فراهم باشد. از اينرو حجم نمونه به ·r نفر براى هر گروه كاهش يافت. لازم به ذكر است توان آمارى نشان از كفايت حجم نمونه داشت.

$$
n=\frac{2 \sigma^{2}\left(Z_{1-\frac{\alpha}{2}}+Z_{1-\beta}\right)^{2}}{d^{2}}
$$

بدين صورت كه فراخوانى به منظور شركت در يزوهش در انجمن معلولين اصفهان منتشر شد كه پِ از مطلع شدن افراد و ثبت نام در فراخوان تعداد • ع نفر از افراد انتخاب و

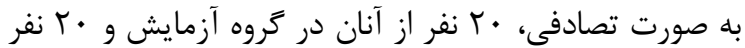
ديكر در گروه كنترل قرار كرفتند. به اين ترتيب كه به هر عضو يك شماره از •ا تا •l تعلق كرفت و سبس همه شمارهها روى تكداى مقوا يادداشت شد و داخل جعبداى قرار داده شد و مقرر شد اولين عدد در قرعه اول به كروه آزمايش و دومين عدد خارج شده به كَروه كنترل اختصاص يابد. سيس به ترتيب به شكل قرعه، يك شماره از جعبه به كروه آزمايش و يك شماره به كروه كنترل اختصاص يافت و كليه افراد در گروههاى كنترل و آزمايش به شكل تصادفى گمارش شدند و كروه آزمايش در 1 جلسه نود دقيقهاى روان

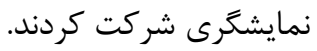
ملاكهاى ورود عبارت بودند از: محدوه سنى ها تا •r سال (لازم به ذكر است علت انتخاب اين دامنه سنى آن بود
(Encounter)، اهميت لحظه اكنون، اهميت لمس و ارتباط غير كلامى، ايجاد تصورات (Imagination)، ارزش طنز و عمق بخشيدن به تئاتر تأكيد دارد مجموع فنون مورد اشاره به تخيله هيجانى و در نتيجه بهبود برخى سازههاى روانشناختى كمك مىنمايد [11] با توجه به آنجه كَفته شد و آمار بالاى معلولان در كشور و اهميت متغيرهاى روانشناختى ذكر شده، بهنظر مىرسد كه لزوم روشهاى جديد و نو براى بهبود زندكى آنان و توجه به اصلاح متغيرهاى روانشناختى در زندكى آنان حائز اهميت است. از سوى ديكر روان نمايشكرى حاوى ساز و كارهايى همجِون ابراز خود و ايفاى نقش است كه مىتواند بر متغيرهاى جرأتورزى، يذيرش بىقيد و شرط خود و روحيه قدردانى مؤثر باشد. بنابراين اين يزوهش با هدف تعيين اثربخشى روان نمايشكَىى بر جرأتمندى، بذيرش خود و روحيه قدردانى در افراد داراى معلوليت جسمى حركتى انجام شد.

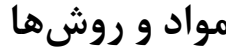

اين يزوهش با روش نيمه آزمايشى (طرح دو كروهى

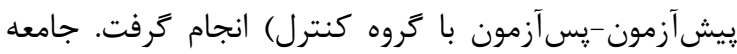
آمارى يزوهش شامل تمامى معلولين جسمى-حركتى در انجمن معلولين اصفهان در سال 9¥ا بود. به منظور انتخاب نمونه از روش در دسترس استفاده شد. به منظور تعيين حجم نمونه از فرمول نمونهكيرى از معادله زير كه در يزوهش Golestanifar و همكارش به كار رفته بود استفاده

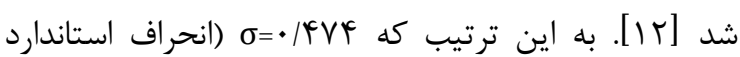
جرأتمندى) و اس//d= (اختلاف ميانگين جرأتمندى در 
4 \& اثربخشى گروه درمانى روان نمايشخرى بر جرأتمندى، هذيرش بى قيد و شرط خود و روحيه قدردانى در افراد ...

مى كردد. از جمله سؤالات آن مىتوان به "من آمادكى يذيرش انتقاد ديخران را دارم" اشاره كرد. همسانى درونى و پايايى بازآزمايى اين آزمون توسط Rambrill و Richey به

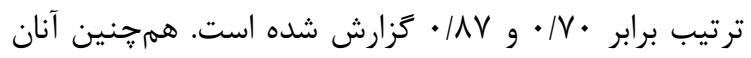
روايى همكَراى آن از طريق همبستكى مثبت و معنادار با ابراز خود نشان دادند [با ]. در ايران نيز Bagheri Panah و ويزگى Jomehri

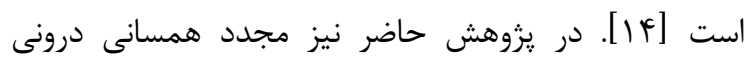
براى نمره كل و ابعاد محاسبه شد كه همغى بالاى •/V.

يرسشنامه يذيرش خود Chamberlain و Haaga: در اين يزوهش بلمنظور بررسى يذيرش خود در افراد داراى معلوليت از يرسشنامه يذيرش خود Chamberlain و |استفاده شد كه مشتمل بر r|Haaga و داراى دو زيرمقياس يذيرش بى قيد و شرط خود و يذيرش مشروط خود است و براى گروه سنى أl سال و بالاتر قابل اجرا است. اين يرسشنامه به صورت مقياس ليكرت هفت

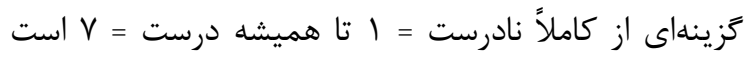

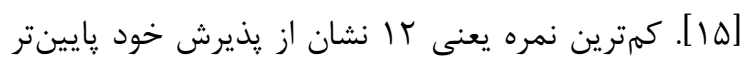
و بالاترين نمره يعنى NF نشان از يذيرش خود بالاتر دارد. همسانى درونى يرسشنامه را با بChamberlain استفاده از آلفاى كرونباخ VT/ • كزارش كردند كه در سطح قابل قبولى است و روايى همخراى آن را با همبستىى مثبت و معنادار بين شادى و عزت نفس با مقياس يذيرش بى قيد و شرط خود نشان دادند. از جمله مواد آن مىتوان به سؤال

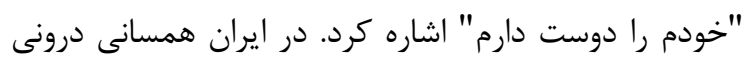
با استفاده از روش آلفاى كرونباخ \$1/ • به دست آمد. هم-
كه مشاهدات كيفى و بررسىهاى انجمن نشان داده بود كه اين كروه در زمينه متغيرهاى وابسته بيشترين دغدغه را داشتند)، داشتن يكى از انواع معلوليت جسمى (معلوليتهاى حركتى نخاعى و معلوليتهاى حركتى غير نخاعى)، داشتن توانايى شناختى لازم براى فراگيرى مطالب و فعاليتهاى لازم و ملاكهاى خروج عبارت بودند از: متعهد نبودن هر يك از اعضاء به كار گروهى، شركت نكردن هريك از اعضاء به طور كامل در ^ جلسه آزمايش، بيمار شدن هر يك از اعضاء در حين انجام مداخلات، ابتلاء به هركونه كم توانى ذهنى (عقب ماندگى ذهنى، عقبماندگى ذهنى ناشى از بيمارىهاى زنتيك و يا سوانح) در كنار معلوليت جسمى. همرجنين اطلاعات دموكرافيك مربوط به جنسيت، نوع معلوليت و سطح تحصيلات نيز مورد توجه قرار ترفت. يرسشنامه جرأتمندى Gambrill و Richey: در اين يزوهش به منظور سنجش جرأتمندى از يرسشنامه

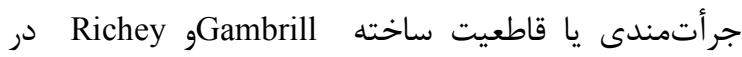
سال 19VD استفاده شد [r/]]. اين مقياس داراى r T ماده شش كزينهاى است كه داراى هشت مؤلفه رد كردن تقاضا، بيان كردن محدوديتهاى خود، تقاضا كردن، يِيشدم شدن در آغاز يك برخورد اجتماعى، بيان احساسات مثبت، كنار آمدن و قبول انتقاد، ابراز وجود و دادن بازخورد منفى مىباشد كه بر اساس طيف ليكرت 9 درجهاى از 1 (كاملاً مخالفم) تا 9 (كاملاً موافقم) نمرهزذارى مىشود كه كمترين نمره يعنى r T نشان دهنده جرأتمندى بالاو بالاترين نمره يعنى זبا نشان دهنده جرأتمندى كمتر است. لازم به ذكر است بر طبق نظر سازندًان اين يرسشنامه، عدد حاصل از جمع نمرات تقسيم بر ده شده و وارد تحليلهاى آمارى 
آلفاى كرونباخ اين يرسشنامه را از VD/• تا FA/• كزارش دادند [1/]]. در اين :زروهش نيز مجدد همسانى درونى محاسبه شد و بالاى V9/ • به دست آمد. يس از كسب مجوز از دانشخاه و مراجعه به انجمن معلولين شهر اصفهان و كسب مجوز و هماهنكى هاى لازم با انجمن جهت بركزارى دوره آموزشى در نه جلسه و هر جلسه به مدت •9 دقيقه بركزار كرديد. اين آموزشها در فضاى باز انجمن معلولين جسمى-حركتى اصفهان و هفتهاى يك روز بين ساعات 9 الى هفت و نيم بعد از ظهر در تيرماه انجام شد. محقق آموزشها را به عهده داشت، قبل از شروع دوره، هر دو تروه در دو مرحله يِيشآزمون، پِآزمون توسط ابزارهاى يزوهش در متغيرهاى وابسته مورد ارزيابى قرار كرفتند. هر دو كروه قبل و بعد از يزوهش يرسشنامها را به شكل دستى تكميل كردند و كسانى كه به علت مشكل حركتى قادر به انجام اين كار نبودند از منشى در خود انجمن كمك گرفته شد. به منظور حفظ اعتبار بيرونى و درونى از كروه آزمايش خواسته شد در خصوص آموزش با ساير اعضاء انجمن معلولين گَفتكويى نشود و به گروه كنترل قول داده شد پِ از اتمام اين دوره آموزشها به آنان نيز ارائه خواهد شد و پِ از اتمام تحليل دادهها، طرح درمان به طور فشرده در جهار جلسه دو ساعته براى كروه كنترل نيز اجرا شد. لازم به ذكر است براى بسته آموزشى اين يزوهش از بسته روان نمايشكرى Abolghasemi استفاده شد كه در جدول 1 مشخصات و تعداد جلسات و تكاليف بيان كرديده است
جنين بايايى آن از طريق دو نيمه كردن آزمون و با استفاده از روش تنصيف Spearman-Brown بو/•به دست آمد [19]. در يزوهش حاضر نيز مجدد همسانى درونى بررسى و براى نمره كل و ابعاد آن بالاتر از سٓ/ • به دست آمد. يرسشنامه قدردانى: در اين يزوهش بلمنظور بررسى روحيه قدردانى در افراد داراى معلوليت از يرسشنامه قدردانى استفاده شد. اين گرسشنامه توسط McCullough و همكاران طراحى شده است و مشتمل بر شش تويه مىباشد كه روى طيف شش درجهاى از كاملاً مخالفم (نمره () تا كاملاً موافقم (نمره ؟) نمرهكذارى مىشود. دو كَويه از سؤالات اين :برسشنامه (كويه بَ و 9)، به صورت معكوس نمرهكذارى مىشوند. بايينترين نمره 9 كه نشان از روحيه قدردانى پايين و بالاترين نمره \&ب است كه نشان از روحيه قدردانى بالا دارد. از جمله كويههاى آن مىتوان به اين عبارت اشاره كرد "روزانه براى موضوعات زيادى شكر گزارم" [IV] هر كويه، ميزان و شدت قدردانى را كه فرد تجربه مى كند، اندازه مى گيرد. اين زيرسشنامه يك مقياس خود كزارشى تك بعدى است كه قدردانى را در كروههاى سنى نوجوان تا بزركسال (دامنه سنى 11 تا VD سال)، را ارزيابى مى كند. سازندًان روايى همكراى آن را با همبستخى مثبت و معنادار بين شادى و عزت نفس با قدردانى و همجنين روايى واكراى آن را با همبستگى منفى و معنادار با حسادت و اضطراب نشان دادند. همسانى درونى اين يرسشنامه بهوسيله روشهاى آلفاى كرونباخ و پايايى تنصيفى بررسى كرديد. در ايران نيزAqababaee و همكاران، نيز در يزوهشى 
ع ع اثربخشى گُروه درمانى روان نمايشگرى بر جرأتمندى، يذيرش بى قيد و شرط خود و روحيه قدردانى در افراد ...

جلدول ا - خلاصه محتواى جلسات آموزشى تروه صرمانى روان نما يشكرى

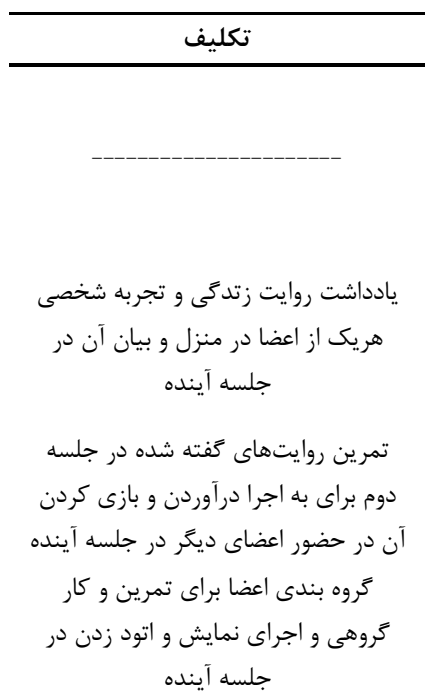

مطالعه بخشى از يك كتاب و داستان و آنوائ

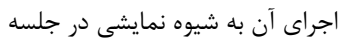
آينده

تمرين آموختههاى جديد در زندكى روزمره

تمرين نمايشنامه و حركات و بيان و بدن

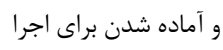

آشنايى اعضاى گروه با يكديگر و مشاور، بيان اهداف گروه

و مسؤوليتهاى رهبر و اعضاى گروه، بيان قوانين و ساختار

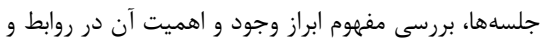

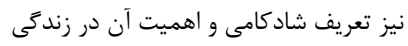

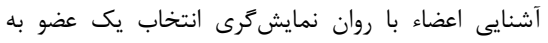

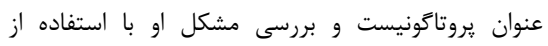

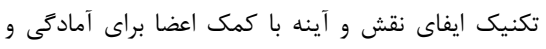
كرم كردن اعضاء

روايت زندگى هر يك از اعضاء و بيان تجربهنهاى شخصى براى اعضاى ديخر

اجرا و بازى كردن روايت زندگى هر يك از اعضاء و تمرين

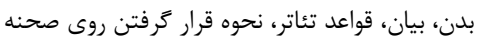

توضيح اهميت حقوق افراد و جَّونكى مطالبه مناسب آن،

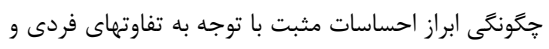

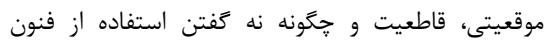
مناسب روان نمايشگرى براى تسهيل و ترغيب اعضا به ابراز

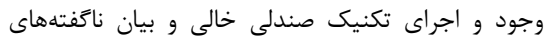

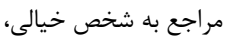
توضيح نقش عواطف و هيجانهاى نشئى مثبت جون شادى،

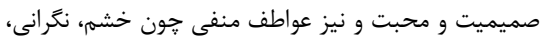

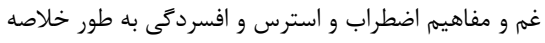

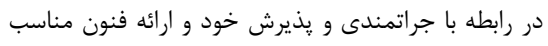

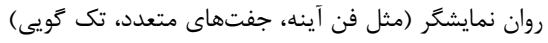
انتخاب و با مشاركت اعضاء به عنوان ياور و در نهايت ارائه

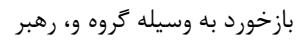

تمرين نمايش شكل گرفته در طى جلسات

$$
\text { كاهش انزوا طلبى و فرصت }
$$

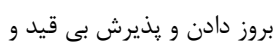

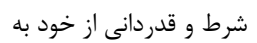

اجراى نمايش در حضور مدعوين خانوادهاى افراد حاضر شدن در حضور جمع و

بررسى گزارش عملكرد اعضاى گروه در زمينه استفاده از

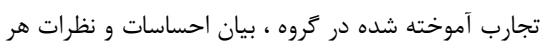

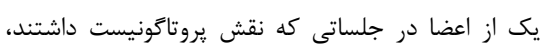

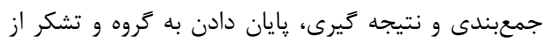
جلسه هفتم وسيله اجراى نمايش ابراز وجود و اجراى نمايش درون

جلسه هشتم

جلسات

جلسه

اول

جلسه

دوم

جلسه

سوم

جلسه

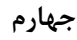

جلسه

ينجمم

جلسه

ششم

نهلم 
(ميانگين و انحراف استاندارد) و آمار استنباطى (تحليل كواريانس جندمتغيره) تجزيه و تحليل شدند. همرجنين براى مقايسه ميانگين سن در دو گروه، از آزمون t مستقل و به منظور مقايسه توزيع فراوانى سطح تحصيلات، نوع معلوليت و جنسيت در دو گروه، از آزمون مجذور كاى استفاده شد. سطح معنى دارى در آزمونها هـ • • در نظر گرفته شد. نتايج

در جدول rا، وضعيت جمعيت شناختى شركت كنند ارائه شده است. نتايج آزمون t مستقل براى سن و نتايج آزمون مجذور كاى براى توزيع فراوانى سطح تحصيلات، جنسيت و نوع معلوليت در دو گروه معنادار نبود (ه •|•P).
IR.IAU.KHUISF.REC.1399.119 اين مطالعه با كد اخلاق در دانشگاه آزاد اسلامى اصفهان (خوراسگان) به ثبت رسيده است. در روند اجراى يروهش، كليه افراد داراى معلوليت جسمى-حركتى با رضايت و رغبت شركت كردند. در همه مراحل اولويت با درمان بيماران بود تا اجراى يزوهش. علاوه بر اين، به آزمودنىها اطمينان داده شد كه در صورت تمايل نتايج به اطلاع آنها خواهد رسيد. در تمام مراحل يزوهش بدون رضايت و اطلاع قبلى افراد عكسبردارى و فيلم بردارى صورت نيذيرفت. همرجنين تمامى ابزارهاى لازم بلهورت رايگان در اختيار آنها قرار گرفت. تجزيه و تحليلهاى آمارى به كمك نرمافزار SPSS نسخه Y T انجام شد. دادهاى گردآورى شده از طريق آمار توصيفى

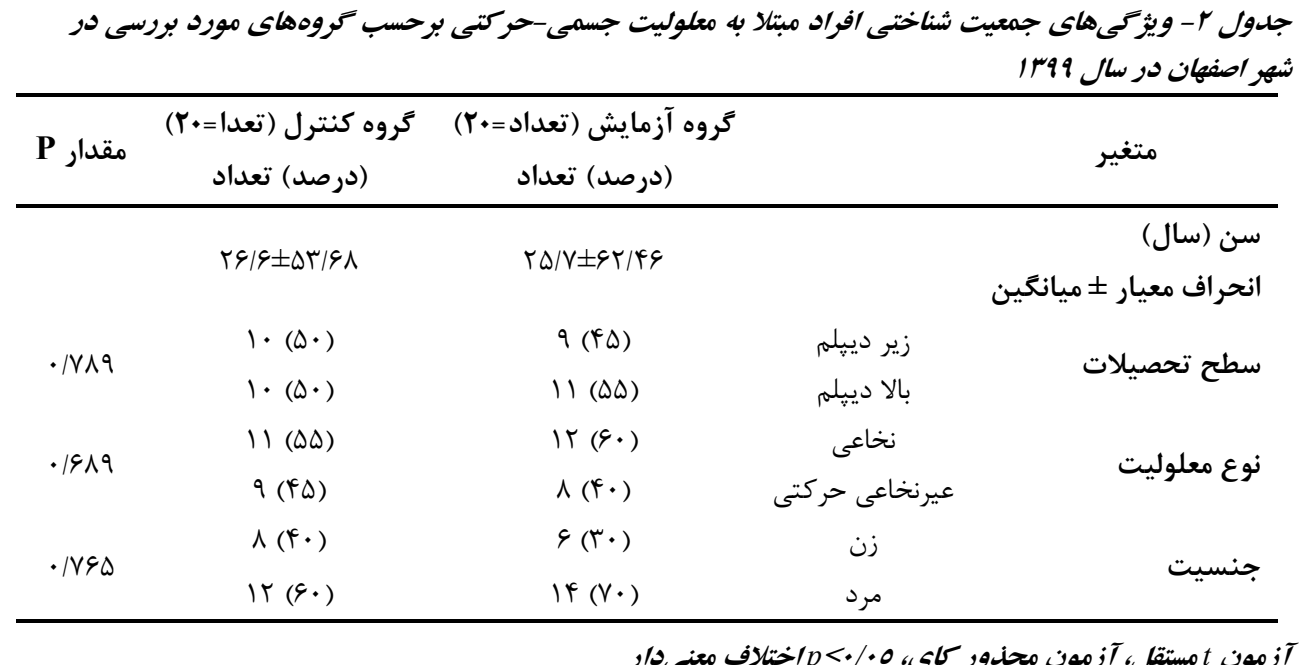

يايينتر نشاندهنده جرأتمندى بيشتر است) و ميانگين نمرات يذيرش خود و روحيه قدردانى در مرحله يسآزمون در مقايسه با مرحله ييشآزمون، نسبت به گروه گَواه، افزايش

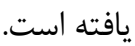

مندرجات جدول r نشان مىدهد كه در گروه آزمايش، ميانگين نمرات جرأتمندى در مرحله يسآزمون در مقايسه با مرحله بِيشآزمون، نسبت به گروه گواه، كاهش يافته است (در مقياس جرأتمندى به كار رفته در اين يزوهش نمرات 
9M1 اثربخشى گروه درمانى روان نمايشكرى بر جرأتمندى، يذيرش بى قيد و شرط خود و روحيه قدردانى در افراد ...

جدول بـ- ميانكين و انحراف استاندارد مثنيرهاى وابسته در افراد مبثلا به معلوليت جسمى-حركتى برحسب

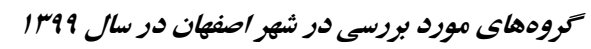

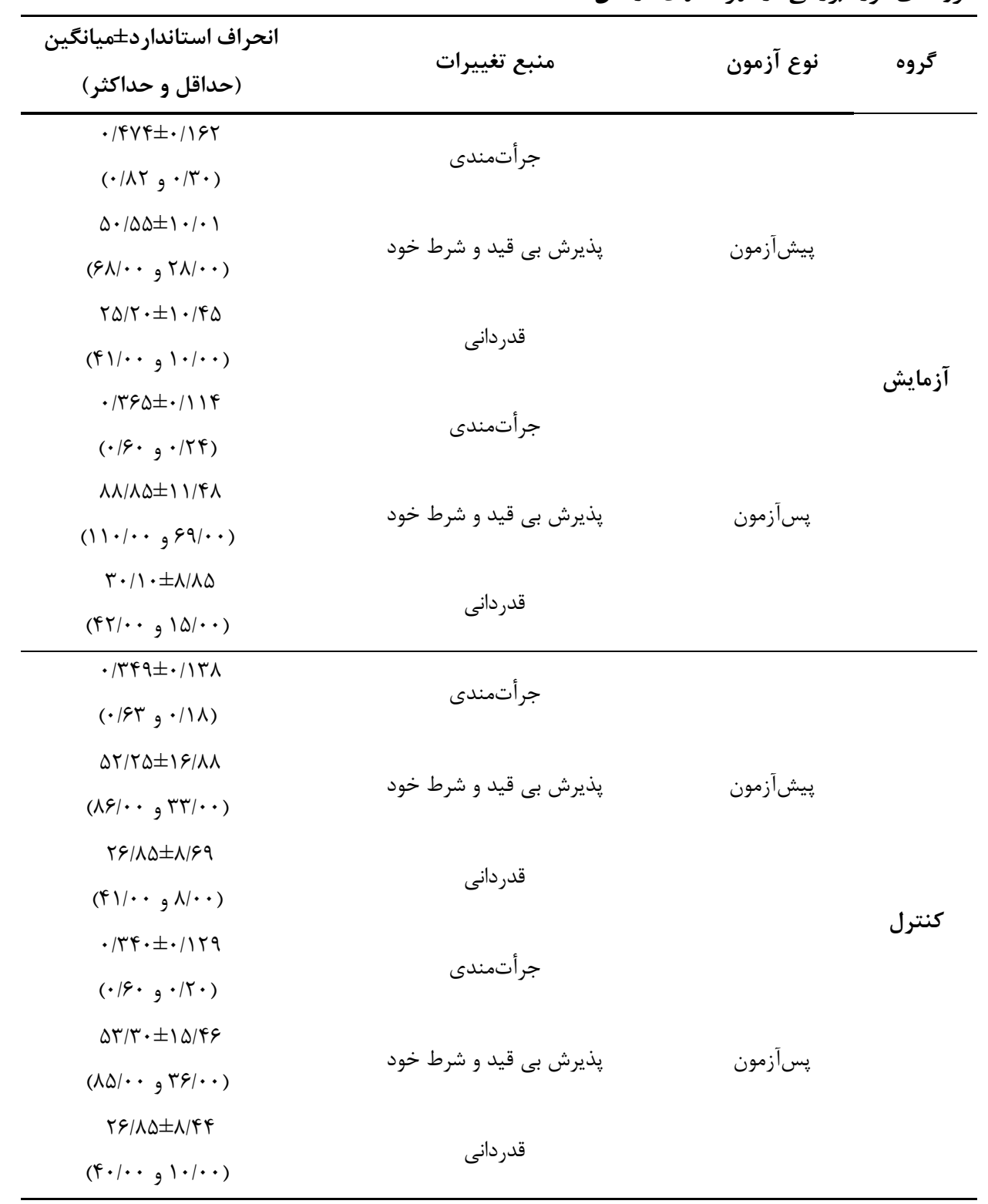

بررسى نرمال بودن نمرات جرأتمندى، يذيرش بى قيد و

شرط خود و روحيه قدردانى از آزمون Shapiro-Wilk

استفاده شد. نتايج نشان داد كه با توجه به مقادير شاخص

توزيع دادهها با اطمينان هو درصد منطبق بر توزيع نرمال
به منظور بررسى معنادارى اين تفاوتها و آزمون فرضيه اصلى از آزمون تحليل كواريانس جند متغيرى استفاده شد. קيش از تحليل دادهها توسط تحليل كواريانس جندمتغيرى، ييشفرضهاى اين نوع تحليل آمارى بررسى شد. براى 
قدردانى از آزمون تحليل كواريانس جند متغيرى استفاده شد. جدول ع نشان مىدهد آزمون اثر پيلايى با ارزش |VDI/، لامبداى ويلكز با ارزش ه•||•، اثر هتلينگ و بزركترين ريشه روى با ارزش

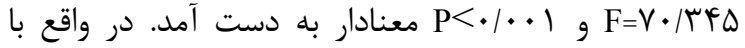
توجه به اثر بيلايى (VDI/•)، D/9 درصد تغييرات در كروه آزمايش در متغيرهاى وابسته ناشى از روان نمايشكَى است. اين بدان معنا است كه روش روان نمايشكرى توانسته است در ميانكين اين متغيرها در كروه آزمايش نسبت به كروه

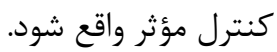

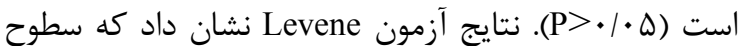
معنادارى به دست آمده براى هر يك از متغيرهاى وابسته بيش از هـ/• است، بنابراين مفروضه همخَى واريانسها در دو گروه برقرار است. به منظور ارزيابى برابرى ماتريس كواريانس متغيرهاى وابسته از آزمون ام باكس استفاده شد و نتايج دال بر عدم تفاوت معنادار ماتريس كواريانساى متغير وابسته در دو گروه مورد بررسى بود (P=•|/NQ)

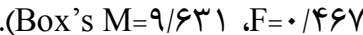
باتوجه به تأييد يِشفرضها به منظور مقايسه دو گروه بر جرأتمندى، يذيرش بىقيد و شرط خود و روحيه

جلدول ع- نتا يج تحليل كواريانس جندمتغيره براى اثر اصلى متغير روان نما يشكَى بر متغيرهاى

وابسته در افراد مبتلا به معلوليت جسمى_حركتى در شهر اصفهان در سال وج"|

\begin{tabular}{|c|c|c|c|c|c|c|}
\hline اندازه & Pقدار P P & درجه آزادى & درجه آزادى & Fقدار F F F F F & ارزش & آزمون \\
\hline.$/ 990$ & $<\cdot 1 \cdot \cdot 1$ & $1 / \cdots$ & $19 / \cdots$ & $V \cdot / H F \Delta$ & $\cdot \mid V \Delta I$ & اثر يِيلايیى \\
\hline.$/ 990$ & $<\cdot / \cdot \cdot 1$ & $1 / \cdots$ & $19 / \cdots$ & $V \cdot / T F \Delta$ &.$/ 1 \cdot r$ & لامبداى ويلكز \\
\hline.$/ 990$ & $<\cdot 1 \cdot \cdot 1$ & $1 / \cdots$ & $19 / \cdots$ & $V \cdot / H F \Delta$ & rqV४/9D & اثرهتلينَ \\
\hline.$/ 990$ & $<\cdot 1 \cdot \cdot 1$ & $1 / \cdots$ & $19 / \cdots$ & $V \cdot / T E \Delta$ & rqVद/9D & بزرَترين ريشه روى \\
\hline
\end{tabular}

آمارى يذيرش بى قيد و شرط خود و روحيه قدردانى معادل

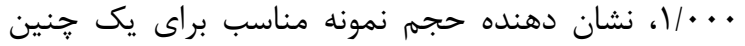
نتيجه گيرى است. به اين ترتيب در پاسخ به اين فرضيه اصلى مىتوان كفت كروه درمانى روان نمايشكَى بر جرأتمندى، پذيرش بى قيد و شرط خود و روحيه قدردانى افراد داراى معلوليت جسمى -حركتى تأثير معنادار دارد.
همانطور كه در جدول ه ملاحظه مىشود، تفاوت ميانگين در دو كروه در جرأتمندى، بذيرش بى قيد و شرط خود و روحيه قدردانى معنادار است. همرجنين ضريب إِا نشان مىدهد كه كروه درمانى روان نمايشكرى /T/ درصد از تغييرات جرأتمندى، ه/ه درصد از تغييرات يذيرش بى قيد و شرط خود و / / ع درصد از تغييرات روحيه قدردانى را تبيين مى كند. توان آمارى جرأتمندى معادل 9VV • و و توان 
• وع اثربخشى گروه درمانى روان نمايشگرى بر جرأتمندى، پذيرش بى قيد و شرط خود و روحيه قدردانى در افراد ...

\begin{tabular}{|c|c|c|c|c|c|c|c|c|}
\hline 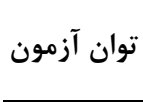 & مجذور إِا & مقدار P & Fقدار F & مجانغَين & آزادى & مجموع مجذورات & منبع تغييرات & نوع آزمون \\
\hline 1 & $\cdot|\mathrm{A}| \mathrm{r}$ & $<\cdot / \cdot \cdot 1$ & DQTKRT &.$/ 149$ & 1 & $\cdot / 148$ & جرأتمندى & \\
\hline 1 & $\cdot / F V t$ & $<\cdot / \cdot \cdot 1$ & TI/DTE & $1 r r \cdot 1199$ & 1 & $1 \pi r \cdot 1199$ & يذيرش بى قيد و شرط خود & 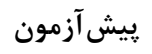 \\
\hline 1 & $\cdot / 1 \vee q$ & $<\cdot / \cdot \cdot 1$ & $r \Delta F / V I I$ & $|r| \cdot|\mathrm{A}| \mathrm{V}$ & 1 & $|r| \cdot|\mathrm{A}| \mathrm{V}$ & روحيه قدردانى & \\
\hline.$/ 9 \vee V$ & 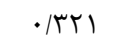 & $<\cdot / \cdot \cdot 1$ & $\mid \varepsilon / \Delta F V$ & $.1 \cdot 19$ & 1 & $.1 \cdot 19$ & جرأتمندى & \\
\hline 1 & $\cdot \mid \wedge \Delta \Lambda$ & $<\cdot / \cdot \cdot 1$ & $r 1 \cdot 19 r T$ & 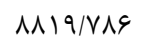 & 1 & 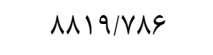 & يذيرش بى قيد و شرط خود & تروه \\
\hline \multirow[t]{4}{*}{1} & $\cdot / 4 r q$ & $<\cdot 1 \cdot \cdot 1$ & TM/FAt & $10 N / 9 V T$ & 1 & $10 N / 9 V T$ & روحيه قدردانى & \\
\hline & & & & $.1 \cdot \cdot 1$ & ra & 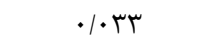 & جرأتمندى & \\
\hline & & & & $f \backslash / \wedge \vee \Delta$ & ra & IFED/ATt & يذيرش بى قيد و شرط خود & 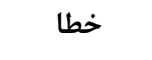 \\
\hline & & & & $F / V \Delta F$ & ro & $199 / \pi \vee 9$ & روحيه قدردانى & \\
\hline
\end{tabular}

بازتوانى هيجانى نشان دادند [1/]، Mardi و همكاران نيز

نشان دادند كه روان نمايشكرى بر اضطراب مؤثر است [rT] در تبيين اين نتايج كه كروه درمانى روان نمايشكرى بر جرأتمندى تأثير داشته است مىتوان كَفت: گَروه درمانى به عنوان شيوهاى اثربخش و از لحاظ زمانى و اقتصادى به صرفه و با توجه به نقش گروه گزينه كارآمدى براى پِيش گيرى در سطوح مختلف و درمان اختلالات مختلف در جامعه است. در فرآيند روان نمايشَّى كه يك فعاليت گروهى است، افراد در فرآيند اصلى آفرينش شركت دارند؛ آنها بايد كارشان را رانسا با ديخران به اشتراك بحذارند و در اين ميان راجع به كارشان

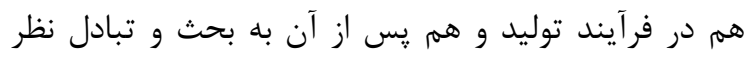
بيردازند. آنها در صحنه خود را ديده و سرانجام اين خود فكرى به خوديابى مىانجامد. آنها به كاستىهاى خود

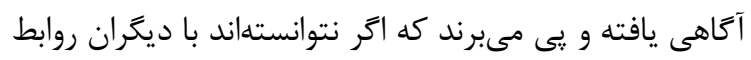
دوستانه برقرار كنند و تنها ماندهاند به علت اين بوده كه از

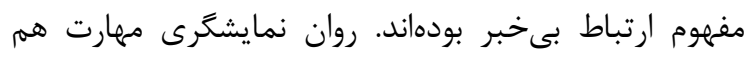
سويى با شرايط و درك بيشتر احساسات طرف مقابل و
يزوهش حاضر با هدف تعيين اثربخشى گروه درمانى روان نمايشگرى بر جرأتمندى، يذيرش بى قيد و شرط خود و روحيه قدردانى در افراد داراى معلوليت جسمى حركتى انجام شد. نتايج نشان داد گروه درمانى روان نمايشكرى بر

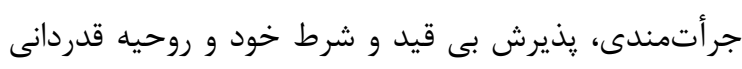
افراد داراى معلوليت جسمى -حركتى تأثير معنادار دارد. تاكنون يزوهشى در زمينه اثربخشى تروه درمانى روان نمايشگرى بر جرأتمندى، يذيرش بى قيد و شرط خود و ومينه روحيه قدردانى در افراد داراى معلوليت انجام نشده كه بتوان همسويى يا ناهمسويى آن را با ساير يافتههاى يزوهشى بررسى كرد اما نتايج يزوهش حاضر با ساير يزوهشها كه اثربخشى اين روش را بر ساير متغيرها نشان دادهاند همسو مىباشد. براى مثال Abolghasemi اثربخشى اين روش را بر بهبود اعتماد به نفس نشان داد [19] Sadeghian، Etemadi

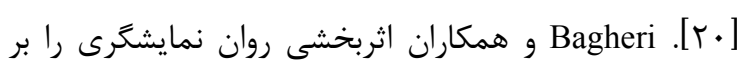


طـور كلى، احساس مطلوب مىنمايد. هنكامى كه فرد اين احساس را به خوبى تجربه كند، خود را قدردان و سِاسكزار كسانى مىداند كه به نحوى موجب بهزيستى و رفاه او شدهاند. به نظر مىرسد، ايـن رابطـهـه رابطــاى دو سويهاى است، از يكسو، افرادى كه قدردان ديكَران باشـند، نخــرش مثبــت ديخــران را بـهـ خـود ايجـاد مى كنند و از سوى ديكر اين نكَرش مثبت ديكران موجب نشاط بيشتر آنها مىشود كه همه اين عوامل در كنار يكديكر باعث شده تا شركتكنندكان بيش از پيش خودشان را بيذيرند و با تمرينهاى عملى اين ويزَى در آنان بهبود يابد. در تببين اثربخشى اين روش بر قدردانى مىتوان كفت: قدردانى يك هيجان همرلانه است كه با احساسات قدرشناسانه در پاسخ به يك سود يا منفعت مشخص مىشود،

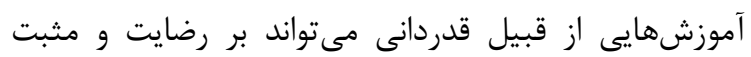
انديشى افراد تأثير كذاشته و نهايتاً باعث افزايش اعتماد بنفس بيشتر آنها شود. DiBlasio و Proctor در يزوهش جداكانهاى نشان دادند كه قدردانى به بهبود روابط، ابراز مناسب خشم و التيام زخمهاى عاطفى كمك مى كند [ [؟. ITF در واقع مىتوان كفت با قدردانى، انكَيزه براى بهبود روابط با فرد خير ارتقاء مىيابد. قدردانى يكى از راههاى رسيدن به آرامش و افزايش تحمل استرس است و فرد قدردان در يرتو قدردانى خود و به دست آوردن جتر حمايت اجتماعى، اين احساس دوست داشته شدن را به صورت مطلوب درى خواهد كرد و در كنار خود كنجينهاى از افراد را مىبيند كه هميشه در كنار او و حامى او خواهند بود [IV].
روابط ميان فردى را در اين افراد افزايش مىدهد. آموزش كروهى مؤثرتر از فردى است، جرا كه اعضاى گروه علاوه بر آموختن رفتارهاى جرأتمندانه، اين رفتارها را در كروه به خوبى تمرين كرده و به علت جو حاكم در كروه يذيرش

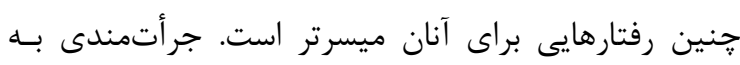
معنى دفاع از حقوق خود و بيان افكار و احساسات به شيوه مستقيم، صادقانه و مناسب است. افراد قاطع بـراى خـود و

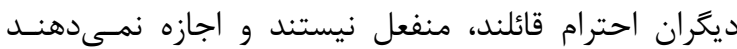

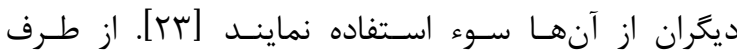

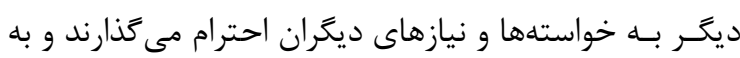
شيوهاى مدبرانه با آنها ارتباط برقرار مىنمايند. اين آموزشها و تمرين ها طى تكاليف هر جلسه در زندگى روزمره استفاده شده و باعث شده تا شركت كنندكان آموختههاىشان را نهادينه كرده و در نتيجه جرأتمندى

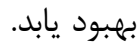
در تبيين اثربخشى اين روش بر پذيرش بى قيد و شرط خود بايد كَفت: آمـوزش روان نمايشكَى باعث افزايسش اعتماد به نفـس مىشود [19]. عزت نفس مبتنى برخوديذيرى است؛ يذيرش خود به اين معنى است كه شما

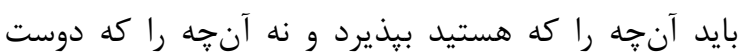
داريد باشيد و بايد ويزگى هاى خوب و بد خود را بيذيريد. خوديذيرى نقطهاى است كه مردم در آن با تمام ضعفهايى كه دارند خود را مىيذيرند و زمانى كه عيبهاى خود را مىيذيرند سعى مى كنند كه با وجود آنها خود را دوست داشته باشند. در گروه درمانى روان نمايشكَى فرد از جانب

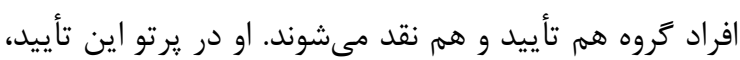

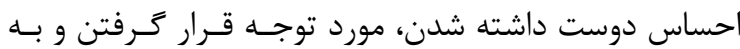


זو 99 اثربخشى گروه درمانى روان نمايشخرى بر جرأتمندى، يذيرش بى قيدو شرط خود و روحيه قدردانى در افراد ...

هيجانهاى منفى آزاد مىشود راحتتر مىانديشند و فرصت آزمون و خطا پِيدا مى كنند و رفتارهاى جديد را آزمايش مى كنند [ • [] (رفتار جرأتمندانه، پٍيرش خود و قدردانى) و از گروه به صورت بازى بازخورد مى گيرند و به يك بينش در مورد رفتارهايشان مىرسند. به نوعى روان نمايشكرى آزمايشى را فراهم مى كند كه درون آن دنيايى را كه دوست

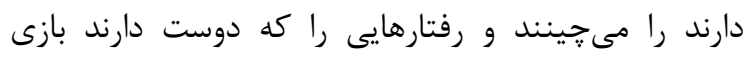
مى كنند و كارگردان نقش مهمى براى تثبيت اين اخلاقيات دارند. معلوليت باعث مىشود كه هيجانهاى منفى به فرد دست دهد و به انزوا برود و اعتماد به نفس خود را از دست دهد. روان نمايشكرى همه اين هيجانات منفى را با نمايش به كنار مىبرد و فرد اماده مىشود كه رفتارهاى جديد را فراگيرد و رفتارهاى جديد، با بازسازى در محيط روان

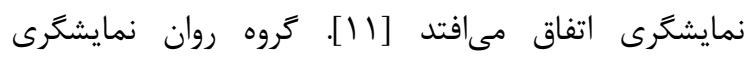
معلولين از افرادى تشكيل شده كه همه از يك درد مشترى به اسم معلوليت رنج مىبرند و باعث شد كه حمايت بيشترى از سوى همنوعان و دوستان بحيرند و بيشتر فعاليت كنند و مسائل عمداى را به نمايش بخذراند. در تبيين اثربخشى اين روش برقدردانى، مىتوان كفت قدردانى يعنى نسبت به جيزهايى كه داريم سياسزار باشيم يا جيزهايى كه باعث شده فوايدى كه براى ما مؤثر است

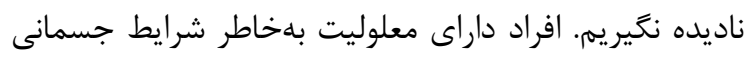
و نياز به كمك افراد ديكر دو حالت را ممكن است تجربه كنند: شرمندگى و يا محبت ديخران را وظايف آنان مىدانند روش روان نمايشكرى با توجه به بازخوردها و فنونش كمك مى كند تا افراد از دريجه نناه ديكران نيز دنيا را بنكرند و به اين ترتيب فرد مىتواند مشكلات ديگران را درك كرده و
با توجه به نكات مذكور קنين مىتوان استدلال كرد كه هر جه بيشتر بتوان به صورت كلامى و يا غير كلامى از افرادى كه فرد را مورد لطف قرار دادهاند سياس گزارى نمايد؛ قدردانى مىتواند به مثابه يك سير محافظ در برابر عوامل استرسزا عمل كند و با افزايش مقاومت روانى، فرد را به مقابله فعال، مؤثر و مسألدمدار تشويق كند. اين امر موجب مىشود تا فرد سياس گزار در بحرانها و موقعيتهاى يرتنش از خود محافظت كند و از سوى ديكر پِاسخهاى مثبت شناختى، عاطفى و رفتارى براى روابط بين شخصى را استفاده نمايد و به همان نسبت مىتواند فهم و درك صحيح از هيجانات خود و ديكران و مديريت آنها متناسب با موقعيت و برخورد درست با مسائل بنيادى زندگى نظير بيمارى و مرك، احساس يوجى و تنهايى داشته باشد [11]، اين امر موجبات تقويت ارتباط با ديخران را فراهم مىسازد و در نتيجه سازوكارهاى مورد نيز باعث مىشود تا قدردانى در

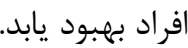
در روان نمايشكَىى افراد به ايفاى نقش مى يردازند، افراد داراى معلوليت با اجراى نقشهايى كه براى آنها در زندكى تجربههاى ناخوشايندى داشته به يك نوع پالايش يا تخليه هيجانى مىرسند؛ دراين روش مشكلاتى كه معلوليت براى آنها رقم زده مثل عدم اعتماد به نفس، خانه نشينى، انزوا و افسردىى و هيجانهاى همراه با اينها به جالش كشيده مىشود، وقتى كارگردان روابط را در روان نمايشكَى براى آنها تسهيل مىكند و باعث مىشود تجربههاى ناكام كنندهاى كه قبلاً معلولين در رابطه با معلوليتشان داشتهاند بازيرورى كردد، باعث مىشود اين هيجانات ناخوشايند برونريزى شود و به يك پالايش برسند و وقتى كه ذهن از 
توانبخشى از اين روش بر بهبود خوديذيرى و جرأتمندى ساير معلولان استفاده ببرند و اثربخشى آن را بررسى نمايند

$$
\text { تا تعميم آن آسانتر كردد. }
$$

\section{نتيجه كيرى}

نتايج اين يروهش نشان داد كه روش روان نمايشگرى روشى مناسب براى بهبود حالات روانشناختى همجون جرأتمندى، يذيرش بدون قد و شرط و قدردانى در بين معلولان جسمى-حركتى است. توصيه مىشود مشاوران توانبخشى براى بهبود حالات روانشناختى معلولين جسمى-حركتى از اين روش بهره ببرند به خصوص كه اين روش مجهز به سازوكارهايى است كه مىتواند به تخليه هيجانى و در يبى آن ساز گارى هيجانى كمك نمايد. تشكر و قدردانى اين مقاله بركرفته از يايان نامه كارشناسى ارشد روانشناسى بالينى مىباشد. نويسندگًان مقاله بر خود لازم مىدانند تا از تمامى كسانى كه ما را در اجراى هرجه بهتر اين گروهش يارى رساندند از جمله معلولين جسمى-حركتى انجمن معلولين اصفهان براى شركت در آموزشها و مسئولين و كاركنان اين انجمن براى ارائه خدمات تسهيل كننده برگزارى آموزش تشكر نماييم.
قدردان احساسات و خدمات خوبى باشد كه از طرف خانواده مى گيرد. در واقع در گروه درمانى رواننمايشخرى وقتى فرد در جاى افراد ديكر (مانند خانوادهاش) قرار مى احساسات آنها را در رابطه با خودش به كمك بازخوردهايى كه از گروه مى گيرد بيشتر درك مى كند. به عنوان مثال در تكنيك آينه وقتى فرد بيرون قرار مى او بازى مى كند مثل اين مىماند كه خودش را از بيرون نگاه كند، باعث مىشود خود را بهتر بشناسد و همرجنين برداشت اطرافيان از خودش را درك كند و به نوعى به تصميمات درستى برسد [بr]. اين يثوهش همجون ساير : پزوهشها محدوديتهايى داشت از جمله اين يزوهش در بين افراد داراى معلويت انجمن معلولين اصفهان صورت پذيرفته است كه در تعميم نتايج به مراكز ديگر و همهزنين بافت فرهنكَى و اجتماعى ساير مناطق بايد احتياط و دقت گردد. همرجنين انتخاب افراد به شكل غير تصادفى بود و آموزشر و محقق يكسان بود كه مىتواند نتايج يزوهش را با محدوديتهايى در زمينه تعميم نتايج روبه رو نمايد. بنابراين ييشنههاد مىشود در ساير يزوهشها آموزش شركت كنند

\section{References}

[1] Zajdel M, Helgeson VS. Communal coping: A multimethod approach with links to relationships and health. J Soc Pers Relat 2020; 37(5): 1700-21.
[2] Oyewole OO, Odusan O, Bodunde OT, Thanni LO, Osalusi BS, Adebanjo AA. Self-acceptance and attitude towards disability among people with 
disability attending a Nigerian tertiary health facility.

J Adv Med Med Res 2017; 21(3): 1-10.

[3] Plexico LW, Erath S, Shores H, Burrus E. Selfacceptance, resilience, coping and satisfaction of life in people who stutter. J Fluency Disord 2019; 59: 5263.

[4] Renshaw TL, Rock DK. Effects of a brief grateful thinking intervention on college students' mental health. Mental Health \& Prevention 2018; 9: 19-24.

[5] Raiser K. The way of ecumenism: Gratitude and commitment. Ecum Rev 2018; 70(1): 35-48.

[6] Perez JA, Peralta CO, Besa FB. Gratitude and life satisfaction: the mediating role of spirituality among Filipinos. J Beliefs Values 2021; 43: 1-12.

[7] Monirpour N, Andisheh G. The effect of group counseling through reciprocal behavior analysis on reducing depression of physical-motor disabilities, Fifth International Conference on Psychology. Educational Sciences and Lifestyle, Qazvin, Takestan Institute of Higher Education; Payame Noor University of Qazvin. 2019. [Farsi]

[8] Golshan A, Zargham Hajebi M, Sobhi-Gharamaleki N. The Effect of Logotherapy Group Training on Changes of Depression, Self-Esteem and Intimacy Attitudes in Physically Disabled Women. IJOHP 2020; 2(2): 101-12. [Farsi]
[9] Heidaripour M, Mashhadi A, Asghari Nekah SM. The effectiveness of social skills training on emotional intelligence of physical-motor disabilities. JRSR 2012; 8(3): 571-80. [Farsi]

[10] Wang Q, Ding F, Chen D, Zhang X, Shen K, Fan Y, et al. Intervention effect of psychodrama on depression and anxiety: A meta-analysis based on Chinese samples. Arts Psychother 2020; 69: 101661.

[11] Kushnir A, Orkibi H. Concretization as a Mechanism of Change in Psychodrama: Procedures and Benefits. Front Physiol 2021; 12: 176.

[12] Golestanifar S, DashtBozorgi Z. Comparing the Effectiveness of Acceptance and Commitment Therapy and Well-being Therapy on Life Expectancy and Psychological Health in Elderly Nonclinical Depressed Patients. JRUMS 2021; 20(3): 297-312. [Farsi]

[13] Gambrill ED, Richey CA. An assertion inventory for use in assessment and research. Behav Ther 1975; 6(4): 550-61.

[14] Bagheri Panah M, Jomheri F. Determining the Effectiveness of Training Life Skills on Improving General Health and Assertiveness in Sexually Abused Female Adolescents. J Community Health 2019; 13(1): 54-63. [Farsi] 
[15] Chamberlain JM, Haaga DA. Unconditional selfacceptance and psychological health. J Ration Emot Cogn Behav Ther 2001; 19(3): 163-76.

[16] Moblian A, Dayarian M, Usefi Z. The role of selfacceptance in relation personality factors and glasser's needs regulation with marital satisfaction. Psychol Sci 2021: 305-16. [Farsi]

[17] McCullough ME, Emmons RA, Tsang J-A. The grateful disposition: a conceptual and empirical topography. J Pers Soc Psychol 2002; 82(1): 112.

[18] Aqababaee N, Farahani H, Fazeli Mehr Abādi A. Measuring Gratitude among University and Religious Students: An Enquiry into the psychometric features of the Gratitude Questionnaire. J of Studies in Islam \& Psychology 2011; 4(6): 75-88. [Farsi]

[19] Abolghasemi S. Surveying the Impact of Teaching Drama Therapy on the Happiness and Self-Esteem Per-University Girls Student. J Soc Work Mag 2015; 3(4): 22-7. [Farsi]

[20] Sadeghian F, Ozra E. The effectiveness of psychodrama group counseling on Organizational feedback and job adjustment among isfahan`s educational employees. JCOC 2011; 3(8): 25-40. [Farsi]
[21] Bagheri M, Saadat F, Pouladi F. The Effectiveness of Psychodrama on Emotional Rehabilitation of Patients with Bipolar I Disorder. Published by Vesnu Publications 2018; 16(2): 81-175. [Farsi]

[22] Mardi N, Arefi M, Momeni K, Amiri H. The Comparison of the Effectiveness of Psychodrama, Reminiscence and Rational-Emotional and Behavioral Treatment on Death Anxiety in the Elderly. Aging Psychology 2020; 6(2): 131-48. [Farsi]

[23] Speed BC, Goldstein BL, Goldfried MR. Assertiveness training: A forgotten evidence-based treatment. Clinical Psychology: Science and Practice 2018; 25(1): e12216.

[24] DiBlasio FA, Proctor JH. Therapists and the clinical use of forgiveness. Am J Fam Ther 1993; 21(2): 17584.

[25] Saffarian Tosi MR, Savabi M, Khouei Nejad G. The Role of Mediatory Factors of Hope and Forgiveness in Personality Traits Effect on Marital Satisfaction of Couples on the Verge of Divorce. J Posit Psychol 2018; 4(2): 71-85

[26] Kellermann PF. Focus on psychodrama: The therapeutic aspects of psychodrama: Jessica Kingsley Publishers; 1992.. 
צوع اثربخشى گروه درمانى روان نمايشگرى بر جرأتمندى، يذيرش بى قيد و شرط خود و روحيه قدردانى در افراد ...

\title{
The Effectiveness of Psychodrama Group Therapy on Assertiveness, Unconditional Acceptance, and the Spirit of Gratitude among Physically Disabled Individuals: A Quasi-Experimental Study
}

\author{
M. A. Makarem', Z. Yousefi ${ }^{r}$
}

Received: 17/03/2021 Sent for Revision: 18/04/2021 Received Revised Manuscript: 13/06/2021 Accepted: 11/07/2021

Background and Objectives: Improving the psychological states of physically disabled individuals can make their lives easier. The purpose of this study was to examine the effectiveness of psychodramas group therapy onassertiveness, self-acceptance, and the spirit of gratitude among physically disabled people in Isfahan.

Materials and Methods: The research method was quasi-experimental with experimental and control groups with a pretest-posttest design. The statistical population of the study consisted of all physically disabled people in Isfahan Disabled People's Association in 2020. Of them, forty subjects were conveniently selected and randomly assigned in two groups (each group 20 persons). The experimental group received eight ninety-minute sessions of psychodrama group therapy while the control group recieved no intervention. To collect information, three questionnaires were used: self-acceptance scale of Gambrill and Ritchie, assertiveness scale of Chamberlain and Haga, and gratitude scale of McCullough. Data were analyzed by descriptive statistics (means and standard deviation) and inferential statistics (multivariate analysis of covariance).

Results: The results showed that psychotherapy group therapy had a significant effect on assertiveness $(p<0.001$, $\mathrm{F}=16.54)$, self-acceptance $(\mathrm{p}<0.001, \mathrm{~F}=210.62)$, and gratitude $(\mathrm{p}<0.001, \mathrm{~F}=33.44)$ of people with physical disabilities.

Conclusion: Psychodrama method was effective in improving assertiveness, unconditional acceptance, and gratitude in people with physical disabilities in Isfahan. Therefore, this method can be considered to improve the mentioned variables among the physically disabled people.

Keywords: Psychodrama, Assertiveness, Self-acceptance, Gratitude, Physically disabled people

Funding: This study did not have any funds.

Conflict of interest: None declared.

Ethical approval: The Ethics Committee of Islamic Azad University of Isfahan (Khorasgan) Branch approved the study (IR.IAU.KHUISF.REC.1399.119).

\footnotetext{
1- MSc Student in Clinical Psychology, Faculty of Psychology and Educational Sciences, Islamic Azad University, Isfahan (Khorasgan) Branch, Isfahan, Iran, ORCID: 0000-0003-0921-071X

2- Assistant Prof., Clinical Psychology Dept., Faculty of Psychology and Educational Sciences, Islamic Azad University, Isfahan (Khorasgan) Branch, Isfahan, Iran, ORCID: 0000-0001-5856-3605

(Corresponding Author) Tel: (031) 3266064, Fax: (031) 35354001, E-mail: z.yousefi@khuisf.ac.ir
}

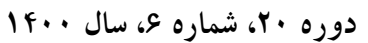

مجله دانشگاه علوم پزشكى رفنججان 
How to cite this article: Makarem MA, Yousefi Z. The Effectiveness of Psychodrama Group Therapy on Assertiveness, Unconditional Acceptance, and the Spirit of Gratitude among Physically disabled Individuals: A Quasi-Experimental Study. $J$ Rafsanjan Univ Med Sci 2021; 20 (6): 681-96. [Farsi] 